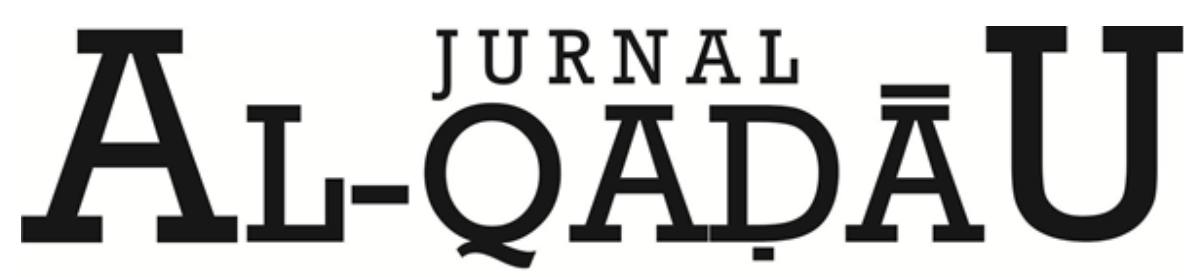

PERADILAN dan HUKUM KELUARGA ISLAM

\title{
Sudut Pandang Feminis Muslim tentang Menutup Aurat
}

\section{Muslim Feminist Viewpoint about Closing the Aurat}

M. Nasir

Dosen Universitas Islam Makassar

Email: muhammadnasir_23@yahoo.com

\begin{tabular}{|c|c|}
\hline $\begin{array}{c}\text { Info } \\
\text { Artikel }\end{array}$ & Abstract \\
\hline $\begin{array}{l}\text { Diterima } \\
04 \\
\text { Februari } \\
2019\end{array}$ & $\begin{array}{l}\text { Fikih aurat dalam ranah beragam pendapat ulama dan cendekiawan } \\
\text { kontemporer. Fikih aurat akan menghasilkan fikih hijab. Dimana hijab } \\
\text { terdiri dari jilbab, khimar, burqah, dir sabīgh, milhafat, dan sebagainya. } \\
\text { Melalui istidlal, para ulama fikih (baca: al-fuqahà ) telah merumuskan } \\
\text { batasan aurat bagi wanita dan pria, baik di luar atau di dalam rumah atau } \\
\text { di dalam ibadah semisal shalat, ihram, dan sebagainya. Istidlal ulama- } \\
\text { ulama ini tidak dianggap mewakili ajaran islam. Maka hadirlah para } \\
\text { cendekiawan kontemporer dengan metode istiqra mengorek kembali } \\
\text { dalil-dalil yang digunakan oleh para ulama dan menghadirkan pandangan } \\
\text { bahwa jilbab itu tidak wajib. Dan dianggap inilah ajaran Islam yang } \\
\text { membebaskan. Dalam penelitian ini, penulis akan mengurai } 4 \text { tokoh } \\
\text { feminis muslim yang dirasa dapat mewakili latarbelakang para penggugat } \\
\text { jilbab. } \\
\text { Kata Kunci : Fiqih, Feminis Muslim, Menutup Aurat }\end{array}$ \\
\hline $\begin{array}{l}\text { Revisi II } \\
04 \\
\text { Maret } \\
2019\end{array}$ & $\begin{array}{l}\text { Fikih aurat diverse opinions of scholars and contemporary scholars. } \\
\text { Jurisprudence Fikih aurat willproduce hijab. Where hijab consists of } \\
\text { jilbab, khimar, burqah, dir sabigh, milhafat, and so on. Through istidlal, } \\
\text { the jurists (read: al-fuqaha) has defined the limits within women and } \\
\text { men, either outside or inside the home or in worship such as prayer, } \\
\text { ihram, and so on. Istidlal these clerics are not considered to represent the } \\
\text { teachings of Islam. When the idea of contemporary scholars with } \\
\text { methods istiqra pry back the arguments used by the scholars and presents } \\
\text { the view that the veil was not obligatory. And this is the doctrine of } \\
\text { Islam is considered liberating. In this study, the authors will parse } 4 \\
\text { Muslim feminist figures were deemed to represent the background of the } \\
\text { plaintiffs jilbab. }\end{array}$ \\
\hline
\end{tabular}

Keywords: Fiqh, Muslim feminists, Closing Aurat 
M. Nasir

\section{A. PENDAHULUAN}

Islam adalah agama universal yang memiliki makna menampakkan ketundukan dan melaksanakan syariah serta menaati apa saja yang datang dari Rasulullah. Semakna dengan hal ini, Allah juga memerintahkan umat Islam agar masuk ke dalam Islam secara keseluruhan (al-kaffah). ${ }^{1}$ Yakni, memerintahkan kaum muslimin untuk mengamalkan syariat Islam dan cabang-cabang iman yang begitu banyak jumlah dan ragamnya. Pun mengamalkan apa saja yang diperintahkan dan meninggalkan seluruh yang dilarang semaksimal mungkin. Termasuk perintah menutup aurat (satr al-'aurah) dan larangan memandang aurat (ghadd al-basar).

Namun, dewasa ini banyak nilai-nilai Islam yang ditinggalkan oleh kaum muslimin, termasuk masalah aurat. Hal ini tampak dari banyaknya kaum muslimah yang tidak mempraktikkan syariat ini dalam keseharian mereka. Akibatnya, mereka kehilangan identitas diri sebagai muslimah sehingga sulit dibedakan mana yang muslimah dan non-muslimah. Menurut Yusuf Al Qardhawi, syariat akan selalu menjalankan fungsinya, selama kaum muslim berpegang teguh kepadanya dan menjalankan hukum-hukumnya. ${ }^{2}$

Di sisi lain, mengingat tidak adanya standar baku bentuk dan model busana atau pakaian yang dirumuskan oleh ulama fikih (al-fuqahä). ${ }^{3}$ Dalam konteks lebih khusus, persoalan busana atau pakaian dibahas oleh sumber-sumber hukum klasik di dalam bab shalat. Para fuqaha membahas bagian tubuh mana yang harus ditutupi oleh laki-laki dan perempuan ketika shalat. Dari sinilah kemudian masalah aurat (bagian pribadi yang harus ditutupi dengan pakaian) dibahas. Dalam shalat laki-laki maupun perempuan muslim harus menutup seluruh auratnya, atau menutupi sesuatu yang oleh hukum dianggap sebagai aurat manusia. Boleh jadi apa yang dianggap aurat ketika shalat juga menjadi aurat di luar shalat. Dengan kata lain, sesuatu yang harus ditutupi dalam shalat juga harus ditutupi ketika di luar shalat. ${ }^{4}$

Fenomena tersebut bisa disebabkan oleh ketidaktahuan, keraguan, ataupun terbelenggu dalam hawa nafsu. Namun, yang lebih bahaya dari itu semua adalah adanya usaha pengkaburkan bahwa jilb $\bar{a} b$ bukanlah sebuah kewajiban agama, melainkan produk budaya Arab. Pengkaburan dari pemikiran yang benar ini telah dilakukan oleh beberapa pihak, baik dari luar umat Islam maupun dari dalam umat Islam sendiri.

1 "Hai orang-orang yang beriman masuklah ke dalam Islam secara keseluruhan (total) dan janganlah kamu ikuti langkah-langkah syetan. Sungguh ia (syetan) musuh yang nyata bagimu." Lihat Departemen Agama RI, Al-Qur'anul Karim Terjemah dan Tajwid Berwarna disertai Tafsir Ringkas Ibnu Katsir, QS. Al-Baqarah/2:208 (Jakarta: Jabal Raudhotul Jannah, 2009), h. 50.

${ }^{2}$ Yusuf Al Qardhawi, Membumikan Syariat Islam, (Bandung: Arasyi Mizan, 2003), h. 41

${ }^{3}$ Kajian di sejumlah literatur fikih, tidak ditemukan pembahasan secara khusus mengenai bentuk dan model busana atau pakaian yang sudah baku. Para fuqaha' menfokuskan kajian pada persoalan 'aurat dan hijab. Dalam pembahsan ini fuqaha' hanya menyinggung jenis-jenis busana/ pakaian yang ada dalam al-Qur'an dan hadis sekaligus melakukan penafsiran atau interpretasi terhadap istilah-istilah yang digunakan oleh kedua sember tersebut dengan mengutip sejumlah pendapat sahabat dan pendapat para mufassir.

${ }^{4}$ Pemhasan bab shalat seperti dalam literatur fikih Islam seperti; Ibnu Rusyd, Bidāyat alMujtahid; Sabiq, Fiqh al-Sunnah karya Al-Sayyid; Al-Fiqh al-Islami Wa Adillatuh karya Wahbah alZuhaily, dan literatur-literatur lainnya. 
Dari dalam tubuh umat Islam, pandangan kurang sedap tersebut pernah dilontarkan oleh beberapa tokoh. Di antaranya adalah Muhammad Sa'id Al-'Asymawi yang beranggapan bahwa jilbäb bukanlah suatu hal yang wajib dengan berdasarkan argumen bahwa konteks turunnya ayat tentang jilbab tersebut dilatarbelakangi oleh situasi kota Madinah yang kala itu belum mempunyai tempat buang hajat di dalam rumah, sehingga ketika hendak buang hajat, mereka harus ketempat sepi di tengah padang pasir. Kesulitan tentu dihadapi oleh wanita muslimah yang ketika akan buang hajat sering diikuti oleh laki-laki iseng yang menyangka bahwa mereka adalah budak. Untuk membedakan antara wanita muslimah dengan budak tersebut. Sehinga dengan memakai jilbab, wanita muslimah dikenali dari pakaian mereka, sehingga mereka terhindar dari gangguan laki-laki iseng. ${ }^{5}$

Bahkan Al-'Asymawi mengklaim bahwa hadis-hadis yang menjadi rujukan tentang pewajiban jilb $\bar{a} b$ atau hijab itu adalah hadis $\overline{a h} \bar{a} d$ yang tak bisa dijadikan landasan hukum tetap. Bila jilbab itu wajib dipakai perempuan, dampaknya akan besar. Seperti kutipannya: "Ungkapan bahwa rambut perempuan adalah aurat karena merupakan mahkota mereka. Setelah itu, nantinya akan diikuti dengan pernyataan bahwa mukanya, yang merupakan singgasana, juga aurat. Suara yang merupakan kekuasaannya, juga aurat; tubuh yang merupakan kerajaannya, juga aurat. Akhirnya, perempuan serba aurat."6 Implikasinya, perempuan tak bisa melakukan aktivitas apaapa sebagai manusia yang diciptakan Allah karena serba aurat. Bahkan tradisi berjilba $\bar{a}$ di kalangan sahabat dan tabi'in, menurut Al-'Asymawi, lebih merupakan keharusan budaya daripada keharusan agama. ${ }^{7}$

Di antara tokoh yang sangat menganjurkan bahkan mewajibkan pemakaian jilbāab ini adalah Abū al-A'la al-Maudūdi. Dalam bahasa yang digunakan oleh alMaududi adalah hija $\overline{a b}$, yang meliputi hijab domestik dan hijab non domestik. Hija $\overline{a b}$ domestik adalah bahwa wanita muslimah dianjurkan tinggal di dalam rumahnya dan menjaga dirinya untuk tidak meninggalkan rumah bahkan untuk melaksanakan salat di masjid berjama'ah. Sedangkan hijab non domestik (publik) adalah dengan memakai pakaian yang tertutup rapat, kecuali apa yang biasa terlihat seperti wajah dan kedua telapak tangan. ${ }^{8}$ Hal yang sama juga diungkapkan oleh Bakar bin Abdullah Abū Zaid. ${ }^{9}$ Bahkan tokoh yang kedua ini lebih ekstrim lagi dalam memahami persoalaan ini. Dia bahkan menganggap bahwa wajah dan telapak tangan wajib untuk ditutup ketika berada di luar rumah atau bertemu dengan non muhrimnya. ${ }^{10}$

Berdasarkan latar belakang di atas, maka persoalan yang menjadi kajian utama dalam penelitian ini yaitu bagaimana sudut pandang feminis muslim tentang menutup aurat.

\footnotetext{
${ }^{5}$ Muhammad Sa'id al-'Asymāwī, Kritik Atas Jilbab, alih bahasa Novriantoni Kahar dan Opie $\mathrm{Tj}$, (Jakarta: Jaringan Islam Liberal dan The Asia Foundation, 2003), h. 12.

${ }^{6}$ Muhammad Sa'id al-‘Asymāwì, Kritik Atas Jilbab, h. 127.

${ }^{7}$ Muhammad Sa'id Al-'Asymawi, Kritik Atas Jilbab, h. 154.

${ }^{8}$ Abù al-A'lā al-Maudūđi, Al-Hijāb, (Beirut: Dār al-Fikr, tt), h. 300.

${ }^{9}$ Bakar bin Abdullah Abū Zaid, Menjaga Kehormatan,alih bahasa: Gunaim Ihsan dan Uzeir Hamdan, (Jakarta: Yayasan as-Shofwa, 2003), h. 30-33.

${ }^{10}$ Bakar bin Abdullah Abū Zaid, Menjaga Kehormatan, h. 30-33.
} 
M. Nasir

\section{B. METODE PENELITIAN}

Penelitian ini adalah tipe penelitian kepustakaan atau library research. Penelitian ini mengumpulkan data-data pustaka yang bertalian dengan fikih yang universal, fikih wanita klasik dan sebagainya. Pendekatan penelitian ini menggunakan fenomenologis dan interaksi simbolik. Dalam menganalisis data, metode yang digunakan adalah kualitatif dengan menggunakan teknik analisis isi (content analysis), ${ }^{11}$ yang meliputi analisis deskriptif, taksonomi, dan interpretatif.

\section{PEMBAHASAN}

\section{Fikih Aurat Menurut Feminis Muslim.}

\section{Muhammad Said Al-'Asymāwi (Teori Kausalitas Jilbāb).}

Permasalahan jilb $\bar{a} b$ menurut Al 'Asymawi muncul dalam wacana pemikiran keislaman setelah beberapa kelompok menyebutnya sebagai kewajiban Islam. Sebagian menghukuminya fardu 'ain, kewajiban individu setiap perempuan muslimah yang sudah baligh. Dari kewajiban ini, muncul tuduhan bagi mereka yang tidak berjilbäb sebagaimana yang ditetapkan kelompok ini, telah keluar dari agama dan mendurhakai syari'at, dan pentas mendapat sanksi yang sepadan dengan ilhad, orang-orang atheis; yaitu hukum bunuh (Idam). Sementara itu, busana yang menyerupai jilbab yang dikenakan gadis-gadis dan perempuan di bebarapa negara non-muslim, oleh kelompok tersebut hanya dianggap sebagai slogan politik belaka, bukan kewajiban agama. Lalu apakah hakikat jilbab, apa yang dimakud dengan jilbab, dan landasan keagamaan apa yang digunakan oleh mereka yang menganggapnya sebagai kewajiban agama, dan mengapa sebagian menganggapnya sebagai hanya slogan politik dan bukan kewajiban agama. $^{12}$

Menurutnya, hijab tidak wajib, karena ayat hijab hanya khusus diturunkan untuk para istri Nabi. Bahkan lebih lanjut ia mengatakan bahwa isu diwajibkannya hijab mempunyai tujuan politis. ${ }^{13}$ Ada kausalitas atau sebab akibat dari turunnya ayah hijab. Atas pemikirannya tersebut, Syeikh al-Azhar secara khusus menulis Bal al-Hijab Haqiqat Syar'iyyat untuk mengkounter pemikiran Al-'Asymawi. ${ }^{14}$ Bahkan secara khusus M.'Imarah (seorang cendekiawan kontemporer Mesir) menganggap Al'Asymawi sebagai pemikir sekuler yang membahayakan. ${ }^{15}$

\footnotetext{
${ }^{11}$ Content analysis adalah suatu teknik penelitian untuk membuat inferensi-inferensi yang dapat ditiru (replecabel). Lihat Klaus Krippendorf, Content Analysis, Introduction to it'sTheory and Methodology. Terj. Farid Wadji dengan judul Analisis Isi, Pengantar Teori dan Methodology; (Jakarta: Rajawali Press, 1991), h. 15. Content Analysis juga dikenal dengan analisis dokumen, analisis aktifitas dokumen, dan analisis informasi. Penjelasan selanjutnya lihat Suharsimi Arikunto, Prosedur Penelitian: Suatu Pendekatan Praktek (Jakarta: Rineka Cipta, 1998), h. 92.

${ }^{12}$ Muhammad Sa'id Al-'Asymawi, Haqiqqat al-Hijab wa Hujjiyat al-Hadì (Kairo: Madbuli alSagïr, 1995), h. 16-19. Dalam versi basaha Indonesia, Kritik Atas Jilbab, alih bahasa Novriantoni Kahar dan Opie Tj, (Jakarta: Jaringan Islam Liberal dan The Asia Foundation, 2003), h. 12.

${ }^{13}$ Al-' Asymāwi, Haqiquat al-Hijäb wa Hujjiyyat al-Hadis, (Kairo: Madbuli, 1995), h. 28.

${ }^{14}$ M. Sayyid al-Thanthawi, “Bal al-Hijab Farị̣ah Syar'iyyah” dalam Al-'Asyamawi, Haqiquat alHijäb wa hujjiyyat al-Hadis, h 25-31.

${ }^{15}$ M. 'Imarah, Suqūt al-Ghuluw al-'Ilmānī, (Kairo: Dār al-Syurūq, 1995), 194.
} 


\section{Muhammad Syahrur (Teori Batas Aurat)}

Kerangka teori yang Syahrur gunakan dalam memformulasi ide-idenya adalah penilaian ajaran Islam yang berdimensi nubuwwah dan risalah. Ia mengklasifikasi kandungan al-Kitab kepada nubuwwah dan risalah. Nubuwwah adalah kumpulan informasi dan pengetahuan tentang kealaman dan kesejarahan yang dengan itu dapat dibedakan antara benar dan salah yang terdapat di alam wujud (realitas empiris). Jadi Nubuwwah bersifat objektif dimana ia berisi kumpulan aturan hukum yang berlaku di alam semesta dan berada di luar kesadaran manusia. Sementara Risalah adalah kumpulan ajaran yang wajib dipatuhi manusia berupa ibadah, mu'amalah, akhlak, dan hukum halal-haram. Risalah bersifat subjektif yang berarti kumpulan aturan hukum yang harus dijadikan sebagai bagian dari kesadaran dalam diri manusia didalam berprilaku. ${ }^{16}$ Selaras dengan itu, al-Kitāb mempunyai sifat hanifiyyah dan istiqamah. Hanifiyyah berarti penyimpangan dari garis lurus, sedang istiqamah berarti kualitas sifat dari garis lurus itu sendiri atau yang mengikutinya. Hukum Islam bersifat hanïfiyyah yang bergerak tidak lurus menyesuaikan dengan perubahan yang terjadi di masyarakat. Untuk mengontrol gerak perubahan tersebut, maka mesti ada istiqamah. Dialektika yang terus berjalan seiring antara hanífiyyah dan istiqāmah mengawal perubahan hukum yang tunduk kepada realitas masyarakat. Dengan kata lain, juga dapat dikatakan al-Kitāb menurut Syahrur, didalamnya al-Qur'an yang terdiri dari mutasyabihat dan berdimensi nubuwwah bersifat objektif. Sebaliknya Umm al-Kitab yang terdiri dari muhkamat dan berdimensi risalah bersifat subjektif, dapat berubah dan relatif.

Syahrur menegaskan bahwa al-Qur'an memuat konsep dan prinsip dialektikal paradoksal dan kata al-Qur'an sendiri berasal dari qara-a dan istiqra yang berarti eksplorasi teori Marxisme. Ia mengatakan, "Saya menamakan ayat-ayat nubuwwah sebagai al-Qur'an karena berasal dari kata istiqra (eksplorasi). Dengan al-Qur'an kita dapat mengeksplorasi teori ilmiah tentang materi dan sejarah (materialisme dialektis dan materialisme historis)." Lagi-lagi keilmiahan yang dipertanyakan. Melihat bahasa bahwa al-Qur'an berasal dari istiqrā. Bagaimana mungkin mashdar mujarrad merupakan derivasi dari masdar mazid. Dengan kata lain Syahrur dengan pembacaan ideologi Marxis-nya menjelaskan overlapping-nya antara yang ilmiah dan produk pemikiran dan paradoks pada sistem logika. Begitupun pemaksaan ideologinya dalam interpretasi al-Qur'an telah memaksakan pendapatnya bahwa Tuhan mengakui keberadaan filsafat Marxisme yang menegasikan Tuhan dan agama dengan mencantumkan prinsip-prinsipnya dalam al-Qur'an. ${ }^{17}$

Penafsiran subjektif lainnya yang bernada ideologi Marxis Syahrur yang menyimpulkan adanya perubahan tafsir mengikuti ruang dan tempat berdasar klasifikasinya tentang al-Kitāb kepada hanäiyyah (gerak berubah) dan istiqāmah (lurus tetap) yang memiliki relasi dialektis. Pengertian kacaunya tentang hal itu dapat dibuktikan bahwa antara haniff dan istiqamah sebenarnya sinonim yang berarti lurus, ketetapan, dan tidak ada penyimpangan, sebagaimana ayat yang banyak berbicara hanif

\footnotetext{
${ }^{16}$ Muhammad Syahrur, Al-Kitāb wa Al-Qur'an: Qira'ah Mu'asirah, (Damaskus: Dār al-Ahali, 1990), h. 54, 90, dan 103.

${ }^{17}$ Mahir al-Munajjad, Munāasyat al-Isykāilyyah al-Manhajiyyah fí al-Kitāb wa al-Qur'an, h. $112-113$
} 
M. Nasir

adalah tentang Nabi Ibrahim dan selalu dikaitkan dengan kalimat al-syirk sebagaimana dijelaskan al-Qur'an dan kamus-kamus bahasa arab.

Kerancuan teori tersebut, bagaimana mungkin akan diaplikasikan dalam ayatayat hukum. Maka keganjilan dan kerancuan teori dialektis dan materialis sosial historis meruntuhkan teori aplikasinya, teori batas (nazariyyah al-hudūd). Tapi untuk lebih jelas melihat kekacauan hermeneutika filologinya, kita ambil contoh aplikasi dalam teori batas mengenai pakaian dan aurat wanita. ketika menafsirkan QS. Al-Nür 124: 31, "Atau anak-anak yang belum mengerti tentang aurat wanita". Syahrur mengartikan aurat dengan apa yang membuat seseorang malu apabila terlihat dan aurat tidak berkaitan dengan halal haram, baik dari dekat maupun jauh. Ia membuat contoh, "Apabila ada orang yang botak dan tidak suka orang melihat kepalanya yang botak, maka dia akan memakai rambut palsu, sebab ia menganggap botak kepalanya sebagai aurat. Kemudian ia mengutip hadis Nabi, "Barang siapa menutupi aurat mukmin, niscaya Allah akan menutupi auratnya." Dia berkomentar, menutupi aurat mukmin dalam hadis itu, bukan berarti meletakkan baju padanya agar tidak terlihat. Maka ia menyimpulkan bahwa aurat berangkat dari rasa malu, yakni ketidaksukaan seseorang ketika terlihatnya sesuatu, baik dari tubuhnya maupun perilakunya. Sedang malu menurutnya relatif, berubah-ubah sesuai dengan adat istiadat, zaman, dan tempat. ${ }^{18}$ Maka ketika ada ayat yang menyuruh memakai jilbāb dalam QS. Al-Aḥzāb/33: 59:

"Hai Nabi, katakanlah kepada istri-istrimu, anak-anak perempuanmu, dan istriistri orang mukmin, 'hendaklah mereka mengulurkan jilbabnya ke seluruh tubuh mereka'. Yang demikian itu supaya mereka lebih mudah dikenal, karena itu mereka tidak diganggu."

Dia menafsirkan bahwa ayat diatas berbentuk pengajaran, bukan syari'at, dan turun di Madinah yang menunjukan mesti dipahami secara temporal dengan tujuan keamanan dari dua gangguan, yakni gangguan alam atau cuaca dan sosial yang menyesuaikan dengan tradisi setempat sehingga tidak mengundang cemoohan. ${ }^{19}$

\section{Muhammad Quraish Shihab (Tafsir Perbandingan Ayat Hijab)}

Dalam Al-Qur'an, Allah berfirman tentang jilbāb hanya di satu tempat, yaitu QS. $A 1-A h z \bar{a} b$ /33: 59. Karena itu, selanjutnya ia populer dikenal dengan ayat jilb $\bar{a} b$. Ayat yang dimaksud ialah:

"Hai Nabi katakanlah kepada istri-istrimu, anak-anak perempuanmu, dan istriistri orang mukmin, 'Hendaklah mereka mengulurkan jilbabnya ke seluruh tubuh mereka.' Yang demikian itu supaya mereka lebih mudah untuk dikenal, karena itu mereka tidak diganggu. Dan Allah adalah Maha Pengampun lagi Maha penyayang.".

Dalam menafsirkan ayat di atas, M. Quraish Shihab memiliki pandangan dengan menyatakan bahwa Allah tidak memerintahkan wanita muslimah memakai jilbab. Pendapatnya tersebut ialah sebagai berikut:

\footnotetext{
${ }^{18}$ Muhammad Syahrur, Naḥwa Ușūl Jadìdah, h. 370

${ }^{19}$ Muhammad Syahrur, Naḥwa Ușūl Jadidah, h. 372-374
} 
"Ayat di atas tidak memerintahkan wanita muslimah memakai jilbab, karena agaknya ketika itu sebagian mereka telah memakainya, hanya saja cara memakainya belum mendukung apa yang dikehendaki ayat ini. Kesan ini diperoleh dari redaksi ayat di atas yang menyatakan jilbab mereka dan yang diperintahkan adalah "Hendaklah mereka mengulurkannya." Nah, terhadap mereka yang telah memakai jilbab, tentu lebih-lebih lagi yang belum memakainya, Allah berfirman: "Hendaklah mereka mengulurkan jilbabnya."20

Demikianlah pendapat yang dipegang oleh M. Quraish Shihab hingga sekarang. Hal ini terbukti dari tidak adanya revisi dalam bukunya yang berjudul Tafsir AlMisbah, meskipun sudah banyak masukan dan bantahan terhadap pendapatnya tersebut.

Di samping mengulangi pandangannya tersebut ketika menafsirkan QS. Al-Nür /24: 31, M. Quraish Shihab juga mengulanginya dalam buku Wawasan Al-Qur'an. Tidak hanya itu, ia juga menulis masalah ini secara khusus dalam buku Jilbab Pakaian Wanita Muslimah: Pandangan Ulama Masa Lalu dan Cendekiawan Kontemporer, yang diterbitkan_oleh Pusat Studi Quran dan Lenter Hati. Ia bahkan mempertanyakan hukum jilbāb dengan mengatakan bahwa tidak diragukan lagi bahwa jilb $\bar{a} b$ bagi wanita adalah gambaran identitas seorang muslimah, sebagaimana yang disebut al-Qur'an. Tetapi apa hukumnya? ${ }^{21}$

M. Quraish Shihab juga membuat Sub bab: Pendapat beberapa ulama kontemporer tentang jilbāb yang menjadi pintu masuk untuk menyampaikan pendapat ganjilnya tersebut. Ia menulis:

"Di atas, semoga telah tergambar, tafsir serta pandangan ulama-ulama mutaqaddimin (terdahulu) tentang persoalan jilbab dan batas aurat wanita. Tidak dapat disangkal bahwa pendapat tersebut didukung oleh banyak ulama kontemporer. Namun amanah ilmiah mengundang penulis untuk mengemukakan pendapat yang berbeda - dan boleh jadi dapat dijadikan bahan pertimbangan dalam menghadapi kenyataan yang ditampilkan oleh mayoritas wanita Muslim dewasa ini". ${ }^{22}$

Selanjutnya, M. Quraish Shihab menyampaikan bahwa jilb $\bar{a} b$ adalah produk budaya Arab dengan menukil pendapat Muhammad Ṭahir ibn 'Āsyūr:

"Kami percaya bahwa adat kebiasaan satu kaum tidak boleh dalam kedudukannya sebagai adat untuk dipaksakan terhadap kaum lain atas nama agama, bahkan tidak dapat dipaksakan pula terhadap kaum itu”.23

Ibnu 'Āsyūr kemudian memberikan beberapa contoh dari Al-Quran dan Sunnah Nabi. Contoh yang diangkatnya dari Al-Quran adalah QS. Al-Ahzāb /33: 59, yang memerintahkan kaum Mukminah agar mengulurkan jilbāb mereka. Tulisnya:

\footnotetext{
${ }^{20}$ M. Quraish Shihab, Tafsir Al-Mishbah, volume 11, h. 321.

${ }^{21}$ M. Quraish Shihab, Wawasan Al-Quran, h. 171.

${ }^{22}$ M. Quraish Shihab, Wawasan Al-Quran, h. 171.

${ }^{23}$ Muhammad Ṭahir Ibn ‘'Āsyūr, Maqāsid al-Syariah al-Islämiyyah, h. 56.
} 
"Di dalam Al-Quran dinyatakan, Wahai Nabi, katakanlah kepada istri-istrimu, anak-anak perempuanmu dan istri-istri orang mukmin; hendaklah mereka mengulurkan jilbabnya ke seluruh tubuh mereka, yang demikian itu supaya mereka lebih mudah dikenal sehingga tidak diganggu. Ini adalah ajaran yang mempertimbangkan adat orang-orang Arab, sehingga bangsa-bangsa lain yang tidak menggunakan jilbab, tidak memperoleh bagian (tidak berlaku bagi mereka) ketentuan ini". ${ }^{4}$

Untuk mempertahankan pendapatnya, M. Quraish Shihab berargumen bahwa meskipun ayat tentang jilb $\bar{a} b$ menggunakan redaksi perintah, tetapi bukan semua perintah dalam Al-Qur'an merupakan perintah wajib. Demikian pula, menurutnya

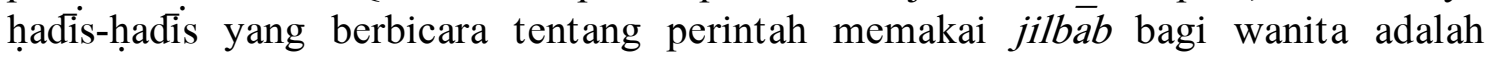
perintah dalam arti "sebaiknya" bukan seharusnya. ${ }^{25}$

M. Qurash Shihab juga menulis hal ini dalam Tafsir Al-Misbah ketika menafsirkan QS. Al-Nür/ 24: 31. Di akhir tulisan tentang jilbāb, M. Qurais Shihab menyimpulkan:

Memang, kita boleh berkata bahwa yang menutup seluruh badannya kecuali wajah dan (telapak) tangannya, menjalankan bunyi teks ayat itu, bahkan mungkin berlebih. Namun dalam saat yang sama kita tidak wajar menyatakan terhadap mereka yang tidak memakai kerudung, atau yang menampakkan tangannya, bahwa mereka "secara pasti telah melanggar petunjuk agama." Bukankah Al-Quran tidak menyebut batas aurat? Para ulama pun ketika membahasnya berbeda pendapat. ${ }^{26}$

Dari pemaparan di atas, dapat diketahui bahwa M. Quraish Shihab memiliki pendapat yang aneh dan ganjil mengenai ayat jilbăb. Secara garis besar, pendapatnya dapat disimpulkan dalam tiga hal. Pertama, menurutnya jilba $\bar{b}$ adalah masalah khilafiyah. Kedua, ia menyimpulkan bahwa ayat-ayat al-Qur'an yang berbicara tentang pakaian wanita mengandung aneka interpretasi dan bahwa al-Qur'an tidak menyebut batas aurat. Ketiga, ia memandang bahwa perintah jilba $\bar{a}$ itu bersifat anjuran dan bukan keharusan, serta lebih merupakan budaya lokal Arab daripada kewajiban agama.

Ibnu Manzur dalam Lisan al- 'Arab mengatakan bahwa jilbāb berarti selendang, atau pakaian lebar yang dipakai wanita untuk menutupi kepada, dada, dan bagian belakang tubuhnya. ${ }^{27}$

Jilbāb berasal dari kata kerja jalaba yang berarti menutupkan sesuatu di atas sesuatu yang lain sehingga tidak dapat dilihat. Dalam masyarakat Islam selanjutnya, jilbăb diartikan sebagai pakaian yang menutupi tubuh seseorang. Bukan hanya kulit tubuhnya tertutup, melainkan juga lekuk dan bentuk tubuhnya tidak kelihatan.

Muhammad bin Sirin berkata, "Aku bertanya kepada Abidah As-Salmani

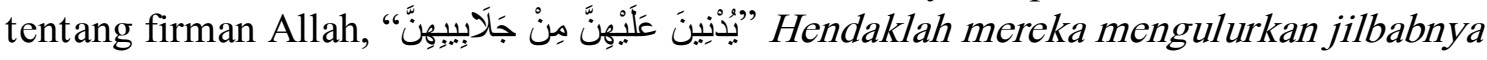

\footnotetext{
${ }^{24}$ M. Quraish Shihab, Wawasan Al-Quran, h. 178-179.

${ }^{25}$ M. Quraish Shihab, Wawasan Al-Quran, h. 178-179.

${ }^{26}$ M. Quraish Shihab, Wawasan Al-Quran, h. 178-179

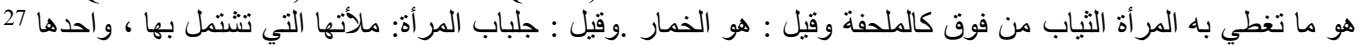

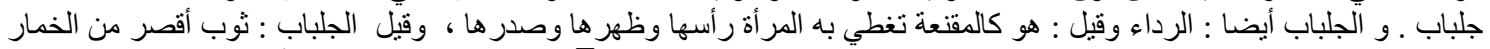
ـ Ibnu Manzūr, Lisān al-'Arab, jilid 1, h. 272.
} 
ke seluruh tubuh mereka" maka ia menutup wajah dan kepalanya, serta hanya memperlihatkan mata kirinya. ${ }^{28}$

Dengan demikian, dapat kita ketahui bahwa para ahli tafsir dari dahulu hingga sekarang telah bersepakat bahwa jilb $\bar{a} b$ adalah sebuah kewajiban agama bagi kaum wanita. Mereka bersepakat tentang wajibnya memakai jilbab dan berbeda pendapat tentang makna mengulurkan jilba $\bar{b}$ : apakah mengulurkan ke seluruh tubuh kecuali satu mata, mengulurkan ke seluruh tubuh kecuali dua mata, atau mengulurkan ke seluruh tubuh kecuali muka. Jadi, pendapat M. Qurais Shihab yang menyatakan bahwa kewajiban mengulurkan jilbab adalah masalah khilafiyah jelas tidak berdasar. Sebab, para ulama ahli tafsir sejak dahulu hingga sekarang telah bersepakat tentang kewajiban memakai jilbāb bagi kaum muslimah. Sebab, perintah tersebut didasari atas dalil baik dari Al-Qur'an maupun hadís dan qarinah (petunjuk) yang sangat kuat.

Dari penafsiran para ulama yang memiliki otoritas dalam tafsir al-Qur'an tersebut dapat ditarik kesimpulan bahwa mereka sepakat atas wajibnya jilba bagi kaum muslimah. Penafsiran mereka sudah diakui kebenarannya dan diamalkan oleh umat Islam selama berabad-abad lamanya. Lalu, bagaimana bila tiba-tiba pendapat tersebut dimentahkan dan disalahkan oleh satu orang yang datang belakangan yang otoritasnya dalam ilmu agama masih dipertanyakan? Apakah dapat diterima oleh logika?

Rupanya M. Quraish Shihab mengkritisi pendapat para ulama yang memiliki otoritas dalam ilmu agama dan sama sekali tidak mengkritisi pendapat tokoh yang dianutnya, baik Muhammad Țăhir ibn 'Āsyūr maupun Al-'Asymawì yang notabenenya penganut paham liberal dan pluralisme agama. Seharusnya M. Quraish Shihab lebih kritis terhadap pendapat kedua tokoh tersebut yang otoritas ilmu agamanya masih diragukan, dan bukannya malah langsung mengikutinya tanpa memberi catatan. Ini jelas menunjukkan sikap ketidakadilan ilmiah. Di samping, perbandingan tersebut memang dipaksakan dan asal mencari pendapat yang longgar.

Dalam menafsirkan QS Al-Nür' 24: 31, Ali Ash-Shabuni menjelaskan bahwa kata khumür adalah jama' dari kata khimäryang berarti sesuatu yang menutupi kepala wanita dan menutupinya dari pandangan laki-laki. Sedangkan kata juyūb adalah jama' dari kata jaib yang artinya dada. Maknanya, hendaklah para wanita muslimah memakai kerudung hingga menutupi dada mereka, agar dada mereka tidak kelihatan sama sekali. Ia melanjutkan, wanita pada masa jahiliyah seperti yang terjadi pada masa jahiliyah modern saat ini berjalan di hadapan laki-laki dengan membuka dada, atau dadanya sengaja diperlihatkan untuk menunjukkan keindahan tubuh dan rambutnya untuk menarik laki-laki. Mereka memakai kerudung pada bagian belakang, sementara dada mereka tetap terbuka lebar. Maka dari itu, wanita-wanita mukminat diperintahkan oleh Allah agar menutupi dada mereka dengan kerudung hingga dada mereka tertutup rapat agar terjaga dari tangan-tangan jahil. ${ }^{29}$

${ }^{28}$ Al-Hafiz Ibnu Kașì, Tafsìr Al-Qur'an Al-Aẓim, jilid 3 (Cet. I; Kairo: Dār al-Ḥadìis, 2003), h. 631.

${ }^{29}$ Muhammad Ali Al-Shabuny, Cahaya Al-Qur'an, Tafsir Tematik Surat An-Nur-Fathir, (terj.) Munirul Abidin, MA, Dari judul Qabasun min Nuril Qur'anil Karim, volume 5(Cet. I; Jakarta: Pustaka Al-Kautsar, 2002), h. 42. 
Ditambah lagi, para ulama juga memberikan beberapa syarat bagi busana muslimah. Syarat-syarat tersebut ialah:

1. Busana tidak boleh berfungsi sebagai perhiasan.

2. Tidak terbuat dari kain tipis yang transparan.

3. Tidak ketat dan mencetak bentuk badan.

4. Tidak menggunakan bahan pewangi yang manusuk hidung.

5. Tidak menyerupai busana laki-laki.

6. Tidak menyerupai busana orang kafir.

7. Busana ini tidak dikenakan untuk tujuan popularitas. ${ }^{30}$

Dari uraian di atas, dapat disimpulkan bahwa batasan aurat dalam Islam sangat jelas. Al-Quran sendiri sudah secara tegas menyebutkan batas aurat wanita, yaitu seluruh tubuh, kecuali yang biasa tampak, yakni muka dan telapak tangan. Para ulama tidak berbeda pendapat tentang masalah ini. Yang berbeda adalah pada masalah: apakah wajah dan telapak tangan wajib ditutup? Sebagian mengatakan wajib menutup wajah, dan sebagian menyatakan wajah boleh dibuka.

Perbedaan pendapat ulama mengenai jilb $\bar{a} b$ itu hanya mengenai batasan aurat antara yang harus ditutup dan yang boleh dibuka (tampak). Perbedaan batas aurat yakni muka dan telapak tangan itu termasuk aurat yang wajib ditutup atau tidak, sedangkan pendapat mengenai hukum ber-jilbäb itu telah disepakati oleh seluruh ulama yang muktabar bahwa hukumnya adalah wajib.

Kemudian Quraish Shihab menyatakan bahwa yang terpenting adalah pakaian terhormat. Penulis menganggap bahwa pernyataan tersebut itu memiliki kerancuan. Karena tidak ada batasan yang pasti yang ditetapkan oleh para ulama mengenai pakaian yang dianggap terhormat.

\section{Nasaruddin Umar (Teori Antropologi Jilbāb)}

Aurat berasal dari bahasa arab. Semua Ulama sepakat akan adanya aurat manusia. ${ }^{31}$ Aurat manusia memiliki perbedaan antara laki-laki dan perempuan. Aurat perempuan seluruh tubuh kecuali muka dan telapak tangan, adapun laki-laki dari pusar sampai lutut.

Namun Nasar mempertanyakan apakah aurat yang dipakai dalam shalat juga berlaku di luar shalat. Nasar mengutip pendapat Imam Hanafi dalam kitabnya Tufhat Al Fuqahăt. ${ }^{32}$ Hanafi memperkenalkan dua jenis aurat, aurat dalam shalat dan aurat di luar shalat. Untuk di luar shalat, Hanafi mendasarkan ini dengan dalil al-Qur'an dalam sebagai berikut:

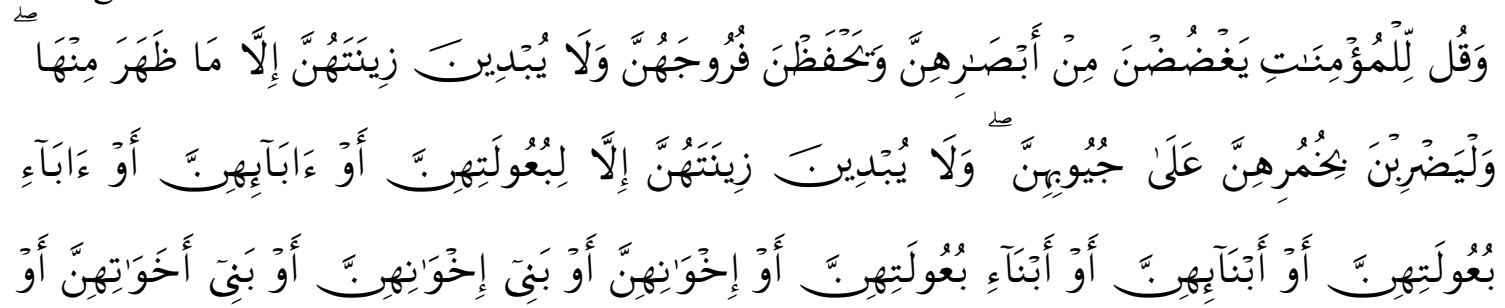

${ }^{30}$ Muhammad Mutawalli Sya'rawi, Fiqih Wanita, h. 54-57. Hal ini juga ditulis oleh Syaikh AlAlbani dalam buku Jilbāb Al-Mar'ah Al-Muslimah fi Kitabi was Sunnah.

${ }^{31}$ Nasaruddin Umar, Fikih Wanita untuk Semua, h. 13. Muhammad Jawad al-Mughniyyah, AlFiqh 'ala al-Mazăhib al-Khamsah, terj. Masykur (Jakarta: Lentera Hati, 1999), h. 87.

${ }^{32}$ Nasaruddin Umar, Fikih Wanita untuk Semua (Jakarta: Serambi, 2010). h. 14. 


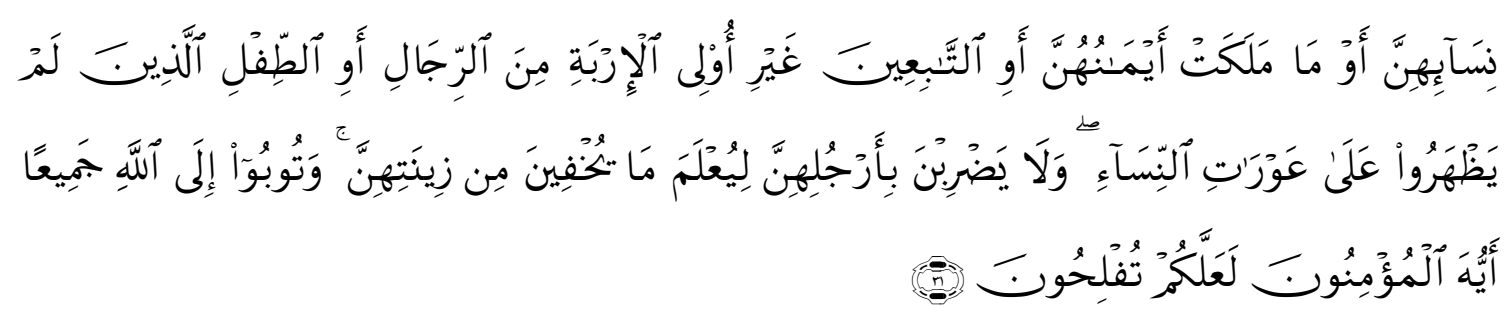

Terjemahan:

Katakanlah kepada wanita yang beriman: "Hendaklah mereka menahan pandangannya, dan kemaluannya, dan janganlah mereka Menampakkan perhiasannya, kecuali yang (biasa) nampak dari padanya. dan hendaklah mereka menutupkan kain kudung kedadanya, dan janganlah Menampakkan perhiasannya kecuali kepada suami mereka, atau ayah mereka, atau ayah suami mereka, atau putera-putera mereka, atau putera-putera suami mereka, atau saudara-saudara laki-laki mereka, atau putera-putera saudara lelaki mereka, atau putera-putera saudara perempuan mereka, atau wanita-Wanita Islam, atau budak- budak yang mereka miliki, atau pelayan-pelayan laki-laki yang tidak mempunyai keinginan (terhadap wanita) atau anak-anak yang belum mengerti tentang aurat wanita. dan janganlah mereka memukulkan kakinyua agar diketahui perhiasan yang mereka sembunyikan. dan bertaubatlah kamu sekalian kepada Allah, Hai orang-orang yang beriman supaya kamu beruntung. ${ }^{33}$

Nasar juga mengutip Ulama seperti Imam Maliki, Imam Syafi'i, Imam Ahmad dan Muhammad Tạahir ibn 'Āsyūr. ${ }^{34}$ Juga mengutip pendapat Ulama Syiah, yaitu Imam Al Khüi dan Imam Khomaeni. Keempat Imam mazhab Sunni sepakat akan aurat wanita seluruh tubuh kecuali muka dan telapak tangan. Berbeda dengan Imam Al-Khūi

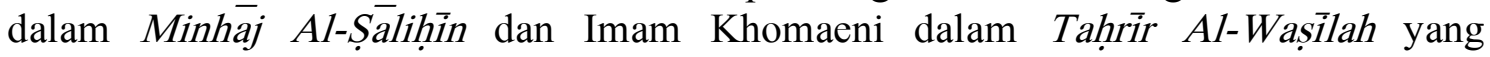
berpendapat bahwa aurat wanita seluruh tubuhnya termasuk wajah dan telapak tangannya. ${ }^{35}$

Kajian fikih Nasar tentang aurat juga dikaitkan dengan tradisi Sasania ${ }^{36}$ dan Persia (kuno) $)^{37}$ yang menggunakan cadar. Dalam disetasinya sangat nampak adanya

\footnotetext{
${ }^{33}$ Departemen Agama RI, Al-Qur'anul Karim Terjemah dan Tajwid Berwarna disertai Tafsir Ringkas Ibnu Katsir, QS. Al-Nur/ 24: 31, h. 548.

${ }^{34}$ Nama lengkapnya Muhammad Ṭahir bin Muhammad Ṭahir bin Muhammad al-Syāazili bin 'Abd Qādir bin Muhammad bin 'Äsyūr, lahir pada tahun 1296 H/1879 M dan wafat pada Ahad, 13 Rajab 1394 H, bertepatan dengan 12 Agustus 1973. Tempat lahir dan wafatnya sama, yaitu di Al-Marsa, dekat kota Tunisia. Keluarga 'Āsyūr terkenal sebagai keluarga religius dan pemikir. Kakek Tahir Ibn ' $\bar{A} s y u ̄ r$, yaitu Muhammad Thahir bin Muhammad al-Syazili, adalah seorang ahli nahwu dan ahli fikih. Ibunya bernama Fatimah. Ibn 'Āsyūr adalah orang pertama yang menafsirkan al-Quran secara sempurna di Tunisia. Kitabnya adalah Tafsir al-Tahrīir wa al-Tanwir. Ia digelari pertama kali dengan sebutan Syaikh Islam dan Syaikh Jami' al-A'zam. Sampai kini di kalangan ulama Timur Tengah, Ibn 'Āsyūr dikenal sebagai salah seorang ulama besar di Tunisia. Ia juga seorang mufassir, ahli bahasa, ahli nahwu, dan ahli sastra. Nasaruddin Umar, Fikih Wanita untuk Semua, h. 18.

${ }^{35}$ Nasaruddin Umar, Fikih Wanita Untuk Semua, h. 13-18.

${ }^{36}$ Salah satu kehilangan yang amat dirasakan oleh dunia internasional, terutama para pencinta dan pemerhati arkeologi, adalah hancurnya kompleks istana era Sasanian, yang berusia lebih Dari 2000 tahun. Bangunan megah dan cagar budaya Iran itu dalam bahasa Persia disebut sebagai "Arg-e Bam" ( $\arg =$ arch dalam bahasa Inggris, artinya: peninggalan) dan memiliki luas kompleks itu sekitar 20 hektar.
} 
kecenderungan mengaikan antropologi pakaian dengan aktualisasi pakaian masa Rasulullah. Nasar memahami penafsiran ayat-ayat al-Qur'an berpihak pada kaum Timur Tengah. Sehingga al-Qur'an dan penafsirannya sangat menjurus kepada Arabisme.

Demikian pula dengan fikih jilb $\bar{a} b$ yang sangat berkaitan dengan aurat. hukum yang mewajibkan pemakaian jilbab ${ }^{38}$ itu adalah salah satu kalimat dalam ayat ke-59 dari surah Al-Ahzab itu sendiri: "yang demikian itu supaya mereka lebih mudah untuk dikenal, karena itu mereka tidak diganggu'. Nasar dalam bukunya membedakan kajian ini. Yakni antara aurat dan jilbab. ${ }^{39}$

Nasar memahami jilb $\bar{a} b$ adalah perintah Allah. Namun konteks jilbäb dipahami Nasar adalah budaya kuno dari peradaban masa lalu. Menurut Eipstein, seperti dikutip Nasaruddin Umar dalam tulisannya, hija $\bar{a}$ sudah dikenal sebelum adanya agama-agama Samawi (Yahudi dan Nasrani atau Kristen). Bahkan Nasaruddin Umar menyebutkan bahwa pakaian yang menutupi kepala dan tubuh wanita itu sudah menjadi wacana dalam Code Bilalama (3.000 SM), kemudian berlanjut di dalam Code Hammurabi (2.000 SM) dan Code (1.500 SM). Ketentuan penggunaan jilb $\bar{a} b$ bahkan sudah dikenal di beberapa kota tua seperti Mesopotamia, Babilonia, dan Asyiria. ${ }^{40}$

Menurut Nasar, ada pengaruh kuat antara peradaban kuno dengan ekspansi jilbāb itu sendiri. Ketika terjadi perang antara Romawi-Byzantium dan Persia, rute perdagangan antar pulau mengalami perubahan untuk menghindari akibat buruk wilayah peperangan. Kota di beberapa pesisir Jazirah Arab tiba-tiba menjadi penting sebagai wilayah transit perdagangan. Wilayah ini juga menjadi alternatif pengungsian dari daerah yang bertikai. Globalisasi peradaban secara besar-besaran terjadi pada masa ini. Kultur Hellenisme-Byzantium dan Mesopotamia-Sasania ikut menyentuh wilayah Arab yang tadinya merupakan geokultural tersendiri. Menurut De Vaux dalam Sure le Voile des Femmes dans l'Orient Ancient, tradisi jilbäb (veil) dan pemisahan perempuan

Bangunan peradaban Sasanian itu terdiri dari tujuh komplek dan sekitar 2000 orang (dulu) hidup di dalamnya. Arge Bam adalah bangunan besar Dari tanah liat pertama di dunia dan memiliki sistem pengairan yang sangat maju. Arge Bam menunjukkan bahwa bangsa Persia adalah pelopor dalam penggunaan teknik pencahayaan bangunan, pengairan, sirkulasi udara, dan penghangatan ruangan. Kunjungi: http://www.irib.ir/. (15 Oktober 2014).

${ }^{37}$ Persia adalah salah satu suku yang tergolong dalam Bangsa Iran, menggunakan bahasa Persia dan juga mempunyai persamaan dalam kebudayaan dengan bangsa Iran yang lainnya. Bangsa ini mayoritas di Iran dan minoritas di beberapa negara-negara lain seperti Afganistan, Tajikistan, $\underline{\text { Uzbekistan, Amerika Serikat, Kuwait, Turki, Uni Emirat Arab, Irak dan juga beberapa negara di Timur }}$ Tengah.

${ }^{38}$ Beberapa negara Islam, pakaian sejenis jilbāb dikenal dengan beberapa istilah, seperti chador di Iran, pardeh di India dan Pakistan, milayat di Libya, abaya di Irak, charshaf di Turki, dan hijâb di beberapa negara Arab-Afrika seperti di Mesir, Sudan, dan Yaman. Terlepas Dari istilah yang digunakan, sebenarnya konsep hijâb bukanlah 'milik' Islam. Misalnya dalam kitab Taurat, kitab suci agama Yahudi, sudah dikenal beberapa istilah yang semakna dengan hijab seperti tif'eret. Demikian pula dalam kitab Injil yang merupakan kitab suci agama Nasrani (Kristen dan Katolik) juga ditemukan istilah semakna. Misalnya istilah zammah, re'alah, zaif dan _ mitpahat. Kunjungi:http://indonesia.faithfreedom.org/forum/silancah-quran-tidak-menyimpang-Dari-kebenarant34454/page40.html. (15 Oktober 2014).

${ }^{39}$ Buku yang dimaksud adalah Fikih Wanita Untuk Semua, lih. Nasaruddin Umar, Fikih Wanita Untuk Semua, h. 13-38.

${ }^{40}$ Nasaruddin Umar, Fikih Wanita untuk Semua, h. 25. 
(seclution of women) bukan tradisi orisinal bangsa Arab, bahkan bukan juga tradisi Talmud dan Bibel. Tokoh-tokoh penting di dalam Bibel, seperti Rebekah yang mengenakan jilba $\bar{a} b$ berasal dari etnis Mesopotamia di mana jilb $\bar{a} b$ merupakan pakaian adat di sana. ${ }^{41}$

\section{PENUTUP}

\section{Kesimpulan.}

Khazanah fikih Islam telah memuat fikih aurat wanita dan bagaimana menutup aurat itu dengan hija $\bar{a}$ dan beragam jenisnya. Persoalah perbedaan pendapat dalam memahami hijab di antara ulama fikih hanya sebatas 3 perkara, yaitu apakah wajah, telapak tangan, dan kaki termasuk aurat. Walau berbeda, titik temuanya adalah sebuah hadis yang menerangkan bahwa wanita dewasa tidak boleh menampakkan tubuhnya kecuali wajah dan telapak tangan. Persoalan hijab ternyata tidak berhenti kala ulama fikih menelurkan karya kitab fikih mereka. Ada sejumlah cendekiawan kontemporer yang berusaha membaca ulang (istiqra) dalil-dalil tentang aurat dan hijāb. Mereka berkesimpulan bahwa jilb $\bar{a} b$ tidak wajib karena 3 hal, yaitu pertama, berdasar $a s \bar{a} \bar{b}$ al-nuzūl, perintah mengulurkan jilbāb ke seluruh tubuh hanya untuk istri Nabi dan wanita mukmin yang merdeka. Kedua, berdasar teori batas aurat. Ketiga, berdasar pendekatan antropologi yang mengatakan bahwa jilb $\bar{a} b$ sudah dibahas dalam banyak peradaban kono seperti Mesopotamia, dan dibahas dalam kitab kekeluargaan Asysyiria (Assyirian code). Keempat, tafsir atas " $m \bar{a}$ zahara minha" atau aurat yang biasa nampak. Jika belahan dada di Bali itu biasa nampak di Bali, maka tidak perlu ditutup.

\section{Implikasi.}

1. Memahami dalil hijab, baik dari al-Quran dan sunnah hendaknya dilihat bagaimana para ulama jumhur memahami dalil-dalil tersebut.

2. Terlepas dari beragam pendapat ulama, dari pemahaman penulis perpegangi bahwa aurat pria dewasa itu adalah antara pusar dan lutut. Aurat wanita dewasa itu seluruh tubuh kecuali muka dan kedua telapak tangan. Wanita tidak boleh menutup wajahnya pada waktu shalat dan ihram.

\footnotetext{
${ }^{41}$ Nasaruddin Umar, Fikih Wanita untuk Semua, h. 26.
} 


\section{DAFTAR PUSTAKA}

Abū Zaid, Bakar bin Abdullah. Menjaga Kehormatan,alih bahasa: Gunaim Ihsan dan Uzeir Hamdan, Jakarta: Yayasan as-Shofwa, 2003.

Al Qardhawi, Yusuf . Membumikan Syariat Islam, Bandung: Arasyi Mizan, 2003.

al-'Asymāwi, Muhammad Sa'id. Kritik Atas Jilbab, alih bahasa Novriantoni Kahar dan Opie Tj, Jakarta: Jaringan Islam Liberal dan The Asia Foundation, 2003.

Abū al-A'lā al-Maudūđi, Al-Hijāb, Beirut: Dār al-Fikr, tt.

Abū 'Abdullāah Al-Qazwayani, Muhammad bin Yazīd, Sunan Ibnu Majah, juz 2. Beirut: Dar al-Fikr, t. Th.

Abū Al-Husain Muslim bin Al-Hajjaj, Șahịh Muslim, juz 8 (Beirut: Dār al-Jail \& Dār al-Afaq al-Jadidah, t. th), h.

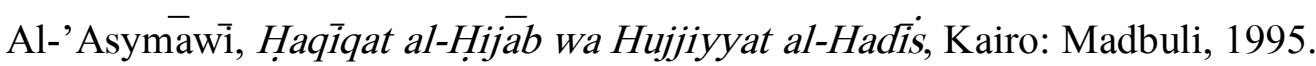

Al-'Asymawi, Muhammad Sa'ìd. Haqiquat al-Hijāb wa Hujjiyat al-Hadìis . Kairo: Madbuli al-Ṣagir, 1995. Kritik Atas Jilbab, alih bahasa Novriantoni Kahar dan Opie Tj, Jakarta: Jaringan Islam Liberal dan The Asia Foundation, 2003.

Al-Munajjad,M̄ahir. Munāqasyat al-Isykāiliyyah al-Manhājiyyah fí al-Kitāb wa alQur'an.

Arikunto, Suharsimi. Prosedur Penelitian: Suatu Pendekatan Praktek, Jakarta: Rineka Cipta, 1998.

Al Shabuni, M. Ali. Tafsìr Rawāi, al-Bayān: Tafsīir àyat al-Aḥkām, Beirut: Dār AlFikr, t. Th.

Al-Thanthawi, M. Sayyid. "Bal al-Hijäb Fariḍah Syar'iyyah” dalam Al-'Asyamawi, Haqiqat al-Hijab wa hujjiyyat al-Hadis.

Departemen Agama RI, Al-Qur'anul Karim Terjemah dan Tajwid Berwarna disertai Tafsir Ringkas Ibnu Katsir, QS. Al-Nur/ 24: 31.

HR. Ahmmad, Abū Dāwūd, Ibnu Majah dari Abū Hurairah. Lih. 'Ilauddin 'A Ti bin Hisam, Kanzu al-'Alam min Sunani al-Aqwal wa al-'Amal, juz 16, ttk: Mu'assasah Al-Risalah, 1981.

Krippendorf, Klaus. Content Analysis, Introduction to it'sTheory and Methodology. Terj. Farid Wadji dengan judul Analisis Isi, Pengantar Teori dan Methodology, Jakarta: Rajawali Press, 1991.

M. 'Imarah, Suqūt al-Ghuluw al-'Ilmānī, (Kairo: Dār al-Syurūq, 1995), 194.

Syahrur, Muhammad. Al-Kitāab wa Al-Qur'ān: Qira'ah Mu'așirah, Damaskus: Dār alAhali, 1990.

Shihab, M. Quraish. Tafsir Al-Mishbah, vol. XI, Jakarta: Lentera Hati, 2008.

Umar, Nasaruddin Fikih Wanita untuk Semua, Lihat juga Muhammad Jawad alMughniyyah, Al-Fiqh 'ala al-Mazahib al-Khamsah, terj. Masykur. Jakarta: Lentera Hati, 1999. 